\title{
ПСИХОЛОГИЧЕСКИЕ СРЕАСТВА
}

\section{КОРРЕКЦИИ АГРЕССИВНОГО ПОВЕАЕНИЯ У ПОАРОСТКОВ, ВОСПИТЫВАЮЩИХСЯ В ПРОБЛЕМНЫХ СЕМЬЯХ}

\section{PSYCHOLOGICAL MEANS OF CORRECTING AGGRESSIVE BEHAVIOR IN ADOLESCENTS BROUGHT UP IN PROBLEM FAMILIES}

\section{Бочанцева Людмила Ивановна}

Доцент кафедры «Педагогики и психологии» Тюменского государственного университета, доцент, кандидат психологических наук E-mail: bochanceva.lyudmila@mail.ru

\section{Городилова Мария Андреевна}

Студент Тюменского государственного университета

E-mail: gorodilova98@yandex.ru

Аннотация. Статья посвящена исследованию влияния психологических средств коррекции на снижение уровня агрессивного поведения у подростков, воспитывающихся в проблемных семьях. В статье раскрыто понятие агрессии, агрессивности и агрессивного поведения в отечественной и зарубежной психологии, раскрывается понятие проблемной семьи и ее влияние на проявления агрессивного поведения у подростков, представлено описание психологических средств коррекции по снижению уровня агрессивного

\section{Bochantseva Lyudmila I.}

Assistant Professor at the Department of Pedagogics and Psychology, University of Tyumen (UTMN), Associate Professor, PhD in Education

E-mail: bochanceva.lyudmila@mail.ru

\section{Gorodilova Maria A.}

Student, University of Tyumen (UTMN)

E-mail: gorodilova98@yandex.ru

Abstract. The article is devoted to a study on the influence of psychological means of correction (individual and group) to reduce the level of aggressive behavior among adolescents who are brought up in problem families. The article reveals the concept of aggression, aggressiveness and aggressive behavior in domestic and foreign psychology, discloses the concept of a problem family and its influence on the manifestations of aggressive behavior in adolescents, describes the psychological means of correction to reduce the level of 
поведения у подростков из проблемных семей. В экспериментальном исследовании было установлено и доказано влияние индивидуальных (консультация/беседа) и групповых (тренинг) психологических средств коррекции по снижению уровня агрессивного поведения у подростков, воспитывающихся в проблемных семьях.

Ключевые слова: агрессия, агрессивность, агрессивное поведение, психологические средства коррекции, проблемная семья, подростки. aggressive behavior in adolescents from problem families. The experimental study revealed and proved the influence of individual (consultation/conversation) and group (training) psychological means of correction to reduce the level of aggressive behavior among adolescents who are brought up in problem families.

Keywords: aggression, aggressiveness, aggressive behavior, psychological means of correction, problem family, teenagers.

В современной психологии одной из основных проблем является агрессивность. Особое беспокойство вызывает то, что с каждым годом число людей, способных проявлять агрессивность, становится все больше и больше [1]. Агрессивность формируется в основном в детском и подростковом возрасте. Но подростковый возраст является наиболее трудным в воспитательном отношении из-за резких изменений в организме (стремление к проявлению взрослости, развитие самооценки, интерес к своим возможностям). Тревожным симптомом является рост числа подростков с проблемным поведением, проявляющемся в агрессивных и конфликтных действиях. Именно в подростковой среде агрессивность отражает одну из острейших социальных проблем нашего общества.

Теоретико-методологической основой нашего исследования являются:

- работы отечественных (С. А. Завражина, Г. М. Андреевой, И. Б. Бойко, В. В. Знакова, Л. П. Колчиной, Т. Г. Румянцевой, Ю. Б. Можгинского, О. О. Савиной, Л. М. Семенюк, И. А. Фурманова, Н. М. Платоновой и др.) и зарубежных исследователей (А. Бандура, Р. Уолтерс, А. Басс, Л. Берковиц, Д. Доллард, Д. Зильман, Э. Фромм), раскрывающих агрессивность как психолого-педагогический феномен;

- исследования О. Кербикова, П. Б. Ганнушкина, А. Е. Личко, К. Леонгарда и др., посвященные изучению личности подросткового возраста с агрессивным поведением;

- исследования проблемных семей в трудах В. А. Борисова, А. Адлера, А. И. Антонова, М. Ю. Арутюняна, Н. К. Бинеевой и др.

- психолого-педагогические исследования отечественных исследователей (Л. С. Выготского, Г. Данилова, А. В. Мудрика, А. С. Макаренко, Е. С. Рогова, Л. М. Семенюк) и зарубежных (Р. Байярд, Д. Байярд, К. Бютнер, М. Раттер) по предупреждению и коррекции агрессивного поведения детей и подростков.

Разработкой проблемы проявлений агрессивности в поведении подростков занимались как отечественные, так и зарубежные ученые: А. Бандура, И. Ю. Кулагина, В. Н. Колюцкий, Р. Ардри, З. Фрейд, К. Г. Юнг, А. А. Реан, С. Л. Соловьев, И. А. Фурманов и др.

В последнее время статистика проблемных семей значительно возрастает. По данным Министерства труда и социального развития РФ, количество неполных семей в нашей 
стране за последние годы выросло до 30\%. По последним статистическим данным, в России 6,2 млн неполных семей. Количество распавшихся браков составляет почти 80\%, а повторных - 30\% от общего числа регистрируемых браков. Семей, употребляющих спиртные напитки, увеличилось на 7,5\%. Как правило, в таких семьях преобладает неблагоприятный психологический климат, который не лучшим образом отражается на детско-родительских и супружеских отношениях. Если же родители ведут себя агрессивно по отношению друг к другу, то, в свою очередь, и дети «наследуют» агрессию, проявляя ее в общении со взрослыми, сверстниками или даже по отношению к самим себе. Актуальность данного исследования определяется тем, что решение проблемы агрессивного поведения у подростков, которые воспитываются в проблемных семьях, требует от психологической науки более тщательного поиска эффективных психологических средств, позволяющих снизить агрессивность у подростков, а также сформировать у них навыки бесконфликтного общения с окружающими.

Анализ психолого-педагогической литературы показал, что понятие «проблемная семья» имеет довольно широкое толкование. К проблемным семьям относятся неблагополучные и дисфункциональные семьи, то есть семьи, в которых нарушено функционирование, низкий уровень состояния психологического комфорта внутри семейного пространства. Вопросами проблемных семей в отечественной и зарубежной психологии и педагогике занимались такие ученые, как В. М. Целуйко, В. А. Борисов, А. Адлер, А. И. Антонов, М. Ю. Арутюнян, Н. К. Бинеева, В. В. Гончаров, Т. А. Гурко, Р. Дрейкурс, О. М. Здравомыслова, А. В. Мудрик, М. С. Мацковский, М. Г. Панкратова, И. С. Кон, В. Д. Попов, М. В. Семина, А. Г. Харчев, С. А. Сорокин и другие.

Ряд ученых отечественных ученых (В. Д. Москаленко, Т. Л. Шибакова, Т. Н. Суслова) ввели понятие «дисфункциональная семья». По их мнению, в такой семье присутствуют жесткие правила поведения, закрепленные за каждым членом семьи, их потребности не удовлетворяются, то есть функционирование в одной или нескольких областях у них нарушено. Вследствие чего заблокированы потребности членов семей в росте, изменениях и самоактуализации.

Такие исследователи, как А. Я. Варга, А. И. Захаров, А. С. Спиваковская и Э. Г. Эйдемиллер, изучали «нормальные» и «ненормальные/нарушенные» детско-родительские отношения и психологический климат в проблемных семьях. В центре их внимания было изучение семейных отношений в проблемных семьях и их влияние на психическое развитие детей. Ученые пытаются найти ответ на вопрос о том, почему у некоторых детей возникают какие-либо расстройства или отклонения в поведении?

Нами были выявлены противоречия между:

- увеличением числа детей подросткового возраста из проблемных семей с ярко выраженным уровнем агрессивного поведения и отсутствием в условиях средней общеобразовательной школы опыта работы с данными нарушениями;

- потребностью средней общеобразовательной школы в методических разработках по коррекции агрессивного поведения подростков из проблемных семей и отсутствием подобных коррекционных программ в общеобразовательной практике.

Целью представленного в статье исследования является теоретическое обоснование и экспериментальная проверка эффективности индивидуальных и групповых 
психологических средств коррекции агрессивного поведения подростков, воспитывающихся в проблемных семьях.

Гипотезой исследования является предположение о том, что коррекция агрессивного поведения подростков, воспитывающихся в проблемных семьях, возможно, будет эффективной, если использовать групповые (тренинг) и индивидуальные (консультация / беседа) психологические средства.

В соответствии с целью и гипотезой исследования поэтапно решались следующие задачи: рассмотрены понятия «агрессия», «агрессивность» И «агрессивное поведение» в психолого-педагогической литературе, раскрыто влияние проблемной семьи на проявления агрессивного поведения у подростков, выявлены и обоснованы возможности психологических средств коррекции агрессивного поведения подростков. В ходе организации опытно-экспериментального исследования по коррекции агрессивного поведения подростков, воспитывающихся в проблемных семьях, необходимо провести оценку эффективности применения индивидуальных и групповых психологических средств.

В ходе анализа психолого-педагогической литературы мы рассмотрели понятия «агрессия», «агрессивность» и «агрессивное поведение». В «Большом психологическом словаре» под редакцией Б. И. Мещерякова и В. П. Зинченко [2] подчеркивается, что «агрессия» (от лат. aggressio 'нападение') представляет собой деструктивное или нарушенное поведение личности, которое противоречит принятым нормам и правилам существования людей в социуме, причиняющее моральный, физический, а также и психологический ущерб [1]. Как мы выяснили, в различных определениях агрессии обязательно присутствует компонент активности в поведении личности, которое другим человеком расценивается как причиняющее ему вред.

Агрессия, по мнению Ю. Б. Можгинского, - это «действия и высказывания, направленные на причинение вреда, душевной и физической боли другому существу» [3].

А. А. Реан под агрессивностью понимает относительно устойчивую черту личности, которая выражается в готовности к агрессии, а также склонности воспринимать и интерпретировать поведение другого человека как враждебное [4].

В «Большом психологическом словаре» [2] «агрессивное поведение» определяется как одна из форм реагирования на различные неблагоприятные в физическом и психическом отношении жизненные ситуации, вызывающие стресс, фрустрацию и тому подобные состояния [1].

Таким образом, агрессию и агрессивное поведение следует рассматривать как конкретные формы деятельности, а агрессивность - как определенное свойство личности.

А. Басс и А. Дарки различают следующие виды агрессии: физическая агрессия (использование физической силы против другого человека); косвенная агрессия (злобные шутки, сплетни, или взрывы ярости, крик, топанье ногами); раздражение (проявление вспыльчивости, резкости, грубости при малейшем возбуждении); негативизм (оппозиционная манера поведения, проявляющийся в формах от пассивного сопротивления до активной борьбы против установившихся обычаев и законов); вербальная агрессия (выражение негативных чувств через вербальные реакции - крик, визг, угрозу, проклятие, ругань) [3]. 
Так как лица подросткового возраста особенно зависимы от микросреды, в которой они воспитываются (то есть семьи), важным является ее нравственная атмосфера, то есть взаимоотношения в семье, которые складываются между ее членами. Агрессивными подростки, как правило, вырастают в тех семьях, где между родителями и детьми мало любви, ласки, понимания, где мало интересуются их развитием, где вместо заботы предпочитают физическое наказание, оскорбления и угрозы [1].

В рамках своего исследования нам необходимо еще определить, что понимается под «проблемной семьей». Многие исследователи к проблемным семьям относят неблагополучные и дисфункциональные семьи, то есть это такие семьи, в которых нарушено функционирование, а также низкий уровень состояния психологического комфорта внутри семейного пространства. Под «проблемной или дисфункциональной семьей» Н. Н. Посысоев понимает семью, в которой порождается неадаптивное, деструктивное поведение одного или нескольких ее членов, в которой существуют условия, препятствующие их личностному росту [5]. Ученым предложена следующая классификация типов проблемных семей: семья с соматически или психически больным ребенком; семья с нарушением внутрисемейной коммуникации; разводящаяся семья; дисгармоничный союз; неполная семья; семья с алкогольной зависимостью; повторный брак [5].

Решая следующую задачу нашего исследования, необходимо теоретически выявить и раскрыть влияние проблемной семьи на проявления агрессивного поведения у подростков. Л. И. Бубнова отмечает, что «спектр причин неблагополучного поведения детей весьма широк. Наиболее главной причиной является возникновение кризисных явлений в семье как важнейшего института социализации ребенка» [6]. Особенностью проблемных семей является то, что в них наблюдается неблагоприятный психологический климат. В таких семьях нарушаются многие функции: воспитательная, хозяйственно-бытовая, коммуникативная или функция духовного общения, психотерапевтическая, функция контроля и опеки за несовершеннолетним ребенком. Обычно в такой семье подросток испытывает физическую и эмоциональную отверженность со стороны родителей, они недостаточно проявляют заботу, внимание к интересам и потребностям, у них отсутствует контроль за успеваемостью в школе и в целом за его поведением [7].

Дети из проблемных семей очень впечатлительны, запоминают неприятные события, происходящие в семье, долго помнят обиду, оскорбление и страх. Особенно такие дети переживают обиду, полученную от родителей. Дети из таких семей уже могут из-за своего жизненного опыта, условий воспитания и отношений в семье эмоционально реагировать на накапливающееся нервно-психическое напряжение [1].

Анализируя научную литературу по психокоррекции, мы установили, что возможными средствами коррекции агрессивного поведения личности могут явиться индивидуальные (например, беседа) и групповые (тренинг) психологические средства. Перечисленные средства коррекции могут применяться для нормализации общения агрессивных подростков, а также и для коррекции их поведения. Все это обусловило наш интерес к данным психологическим средствам. Подчеркнем, что преимуществом беседы является то, что она всегда индивидуализирована, а ее предметом являются особенности поведения и общения подростка. В процессе непринужденной беседы 
педагог-психолог совместно с подростком анализирует складывающиеся взаимоотношения с окружающими, выясняет причину данного поведения. Преимущества социально-психологического тренинга состоит в том, что он, прежде всего, направлен на формирование приемлемых способов взаимодействия с окружающими, обучение контролю и управлению гневом, закрепление навыков саморегуляции своего поведения, а также способствует развитию эмпатии. В групповом психологическом тренинге происходит применение активных методов воздействия. Через применение специфических форм сообщения знаний, обучения навыкам и умениям в сферах общения, деятельности и личностного развития у подростков формируется компетентность в общении и поведении [8]. Данные преимущества обусловили выбор применения беседы и группового тренинга как психологических средств коррекции агрессивного поведения подростков из проблемных семей.

Для проверки гипотезы, выдвинутой в начале нашего исследования, мы провели психолого-педагогический эксперимент. Экспериментальное исследование состояло из трех этапов: констатирующий, формирующий и контрольный. Коротко опишем особенности их проведения.

Целью первого этапа эксперимента (констатирующий этап) является определение уровня агрессивного поведения у подростков из проблемных семей. На данном этапе определялось состояние проблемы в реальной образовательной практике. В результате применения специальных методик диагностики были определены уровни агрессивного поведения у подростков. На основе полученных результатов были сформированы две группы испытуемых - контрольная и экспериментальная, равные по уровню агрессивного поведения.

На формирующем этапе эксперимента были реализованы групповые (тренинг) и индивидуальные (беседа) психологические средства коррекции агрессивного поведения у подростков. Групповой тренинг состоял из комплекса занятий со специальными играми и упражнениями, направленных на снижение агрессивности лиц подросткового возраста. В процессе индивидуальных бесед психологом выяснялись причины нарушений поведения и общения у подростков.

На контрольном этапе эксперимента была проведена повторная диагностика уровня агрессивного поведения у подростков из проблемных семей с применением тех же методик, что и на констатирующем этапе. Сравнительный анализ полученных результатов до и после проведения формирующего этапа эксперимента показал наличие значимых различий у испытуемых контрольной и экспериментальной групп [9]. Сформулированы выводы об эффективности влияния индивидуальных (беседа) и групповых (тренинг) психологических средств коррекции агрессивного поведения подростков из проблемных семей.

Для изучения проявлений агрессивности у подростков, воспитывающихся в проблемных семьях, были применены опросник агрессивности А. Басса и А. Дарки, методика «Агрессивное поведение» Е. П. Ильина и П. А. Ковалева, шкала Кука - Медлей «Диагностика враждебности». Представим показатели и уровни проявления агрессивности, а также методики их диагностики (таблица). 
Показатели агрессивности у подростков и методики их диагностики [1]

\begin{tabular}{|l|l|}
\hline \multicolumn{1}{|c|}{ Показатели агрессивности } & \multicolumn{1}{|c|}{ Методики диагностики } \\
\hline $\begin{array}{l}\text { Физическая, вербальная и косвенная агрессия, раздражение, } \\
\text { проявление негативизма, обиды, подозрительности, осознание } \\
\text { чувства вины }\end{array}$ & $\begin{array}{l}\text { Опросник агрессивности А. Басса и } \\
\text { А. Дарки }\end{array}$ \\
\hline $\begin{array}{l}\text { Склонность к прямой или косвенной вербальной и физической } \\
\text { видам агрессии, уровень несдержанности личности }\end{array}$ & $\begin{array}{l}\text { «Агрессивное поведение» } \\
\text { (Е. П. Ильин, П. А. Ковалев) }\end{array}$ \\
\hline Цинизм, агрессивность и враждебность & $\begin{array}{l}\text { Диагностика враждебности } \\
\text { (по шкале Кука - Медлей) }\end{array}$ \\
\hline
\end{tabular}

Было определено три уровня агрессивного поведения подростков.

Высокий уровень агрессивного поведения предполагает, что такие подростки излишне агрессивны, их действия носят разрушительный характер. Они часто неуравновешенны, бывают жестоки по отношению к другим. Для подростка с высоким уровнем агрессивности характерны частые оскорбления окружающих его лиц, использование ненормативной лексики, выражение отрицательных эмоций как посредством крика, визга, ссоры, так и через содержание словесных высказываний - угрозы, проклятия и ругань. Подросток активно применяет физическую силу против других для причинения им физического и морального вреда. Такие подростки довольно часто дерутся, пинаются, толкают сверстников.

Для среднего уровня агрессивного поведения характерно то, что подростки в меру агрессивны. Иногда обнаруживается склонность к необдуманным поступкам, проявляется незначительная злоба на окружающих. После того, как подростки успокаиваются, зачастую они просят прощения за свою несдержанность. Для подростков со средним уровнем характерны эпизодические проявления агрессии.

Низкий уровень агрессивного поведения свидетельствует о крайне редком проявлении агрессии. Такие подростки миролюбивы и добры в общении с окружающими.

Представим результаты констатирующего этапа эксперимента по методике «Опросник агрессивности А. Басса и А. Дарки» (рис. 1).

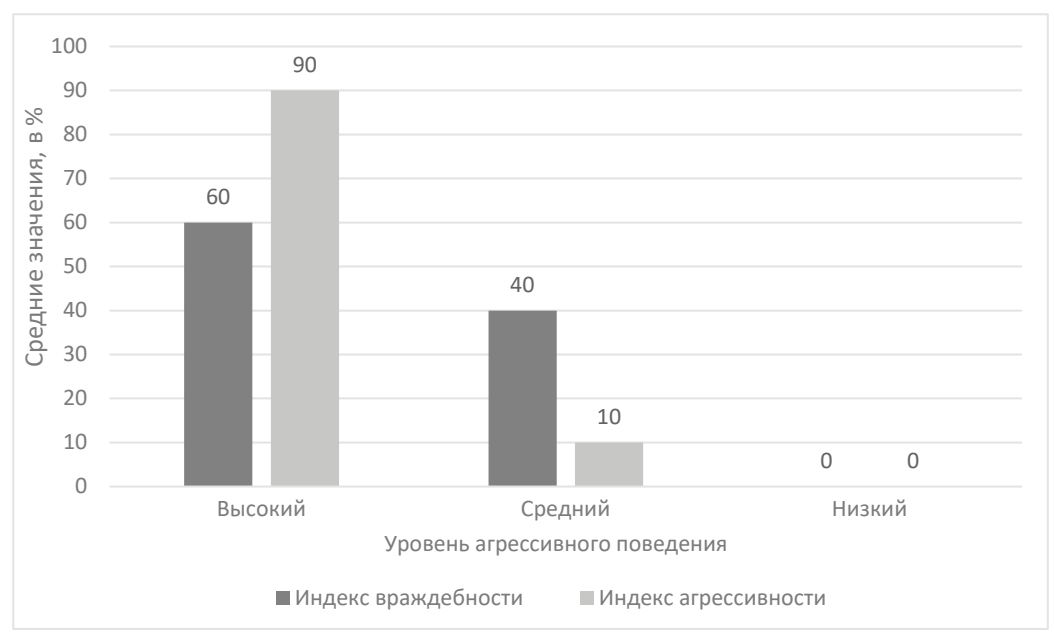

Рис. 1. Результаты по методике «Опросник агрессивности А. Басса и А. Дарки» у испытуемых на констатирующем этапе эксперимента 
Как показывают результаты исследования, высокие показатели по индексу агрессивности были обнаружены у 12 подростков, что составляет 60\%, и средние - у 8 человек (40\%). Высокий уровень по индексу враждебности был обнаружен у 18 подростков из проблемных семей, что составляет 90\%, и средний - у 2 (10\%). Такие подростки чаще, чем другие их сверстники, активно применяют физическую силу, направленную вовне - то есть на окружающих, тем самым демонстрируя готовность к проявлению своих негативных отрицательных эмоций - гнева и ярости даже при незначительном возбуждении. Все это проявляется во вспыльчивости и грубости к окружающим. Для подростков из таких семей характерна оппозиционная манера, проявляющаяся в активной борьбе против устоявшихся норм, правил, традиций и законов общества. Все эти оппозиционные действия подростков обычно адресованы родителям, учителям, сверстникам, с которыми они общаются. Свои негативные чувства и эмоции подростки из проблемных семей выражают через громкий и резкий крик, нецензурные ругательства, угрозы и запугивания.

Результаты исследования по методике «Агрессивное поведение» Е. П. Ильина, П. А. Ковалева показали, что высокий уровень агрессивного поведения был диагностирован у 12 подростков (60\%), средний уровень - у 5 (25\%), низкий - у 3 (15\%). Подростки с высоким уровнем агрессивного поведения свои агрессивные всплески чаще всего направляют на своих сверстников и товарищей в виде постоянного демонстративного крика («Уходи, надоел!», «Не мешай!», «Отстань!», «Ты достал меня!» и пр.) (рис. 2).

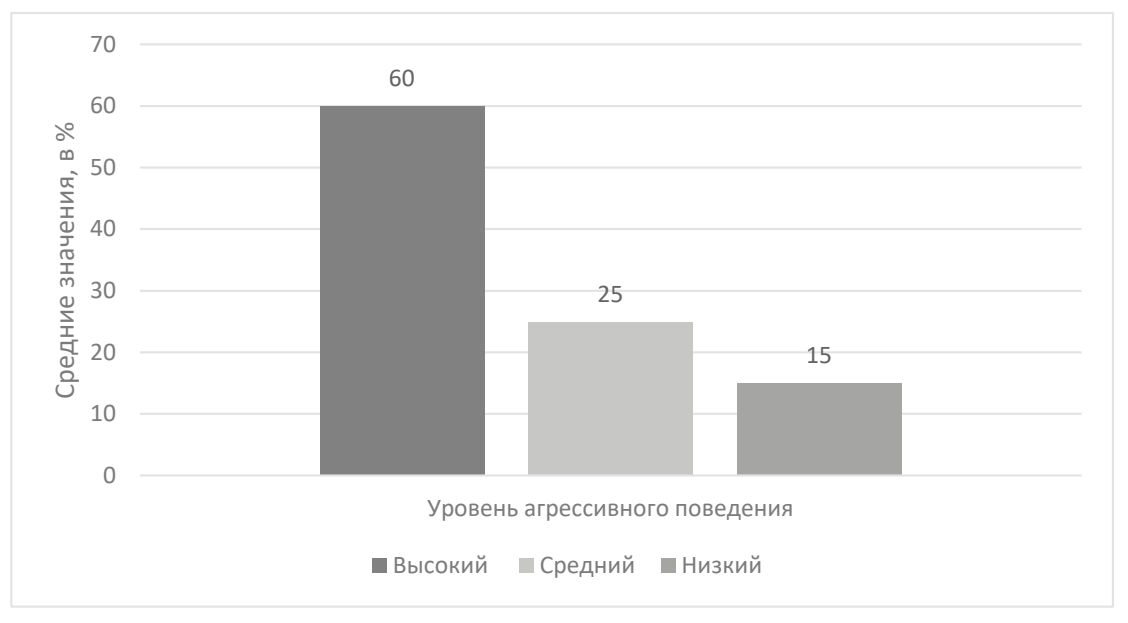

Рис. 2. Результаты по методике «Агрессивное поведение» (Е. П. Ильин,

П. А. Ковалев) у испытуемых на констатирующем этапе эксперимента

Это происходит потому, что в проблемных семьях супруги, взаимодействуя между собой, демонстрируют низкий уровень культуры общения, что воспринимается детьми как норма. Поэтому дети из таких семей копируют родительскую модель общения и поведения. Таким образом, если родители постоянно проявляют агрессию в адрес друг друга и своего ребенка, то и подросток, вырастая в этих неблагоприятных условиях, как правило, проявляет агрессивные вспышки гнева и негативизма по отношению к сверстникам и другим лицам. Своими физическими действиями подростки могут причинить какой-либо материальный ущерб другим людям. К примеру, они могут испортить или уничтожить 
чужую собственность, причинить кому-то физическую боль или унизить того, кто значительно слабее их. Средний и низкий уровни агрессивного поведения были выявлены у незначительного числа испытуемых. Так, 25\% подростков умеренно агрессивны, а 15\% крайне редко проявляют агрессию.

Анализ результатов по методике «Диагностика враждебности (по шкале Кука - Медлей) показал, что высокий уровень враждебного поведения присущ 11 испытуемым (55\%), средний - 9 (45\%), низкий уровень не выявлен (рис. 3).

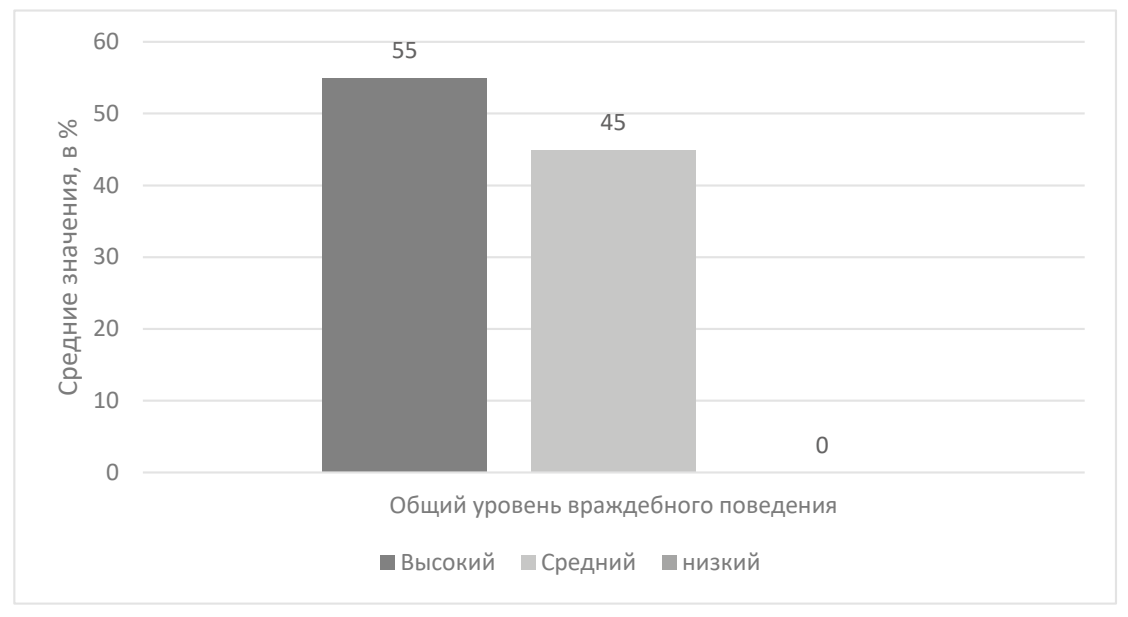

Рис. 3. Результаты по методике «Диагностика враждебности»

(по шкале Кука - Медлей) у испытуемых на констатирующем этапе эксперимента

Подросткам с высоким уровнем враждебности свойственно яркое проявление негативных чувств - непреодолимый гнев, обида или чувство отвращения, выражающиеся по отношению к окружающим или происходящим событиям. Для подростков со средним уровнем присуща умеренная выраженность этих негативных чувств, они демонстрируют некоторую готовность к ним. Таким образом, подростки из проблемных семей характеризуются повышенной агрессивностью и враждебностью по отношению к другим людям.

После анализа результатов по всем методикам на констатирующем этапе эксперимента мы распределили испытуемых в контрольную и экспериментальную группы так, что в них оказалось равное количество человек по уровню агрессивного поведения. Для наглядного представления результатов мы построили гистограмму (рис. 4).

Полученные результаты показывают, что у испытуемых этих групп одинаковый уровень агрессивного поведения. Так, в контрольной группе у 6 (60\%) испытуемых - высокий уровень, у 2 (20\%) - средний и у 2 (20\%) - низкий. В экспериментальной группе высокий уровень у 6 (60\%) испытуемых, средний - у 3 (30\%), низкий - у 1 (10\%). В связи с этим мы будем считать, что группы эквивалентные, достоверных различий не выявлено. Такие подростки нуждаются в коррекционной работе.

Формирующий этап эксперимента был посвящен снижению уровня агрессивного поведения у подростков, воспитывающихся в проблемных семьях, путем применения индивидуальных (беседа) и групповых (тренинг) психологических средств. Целью программы 


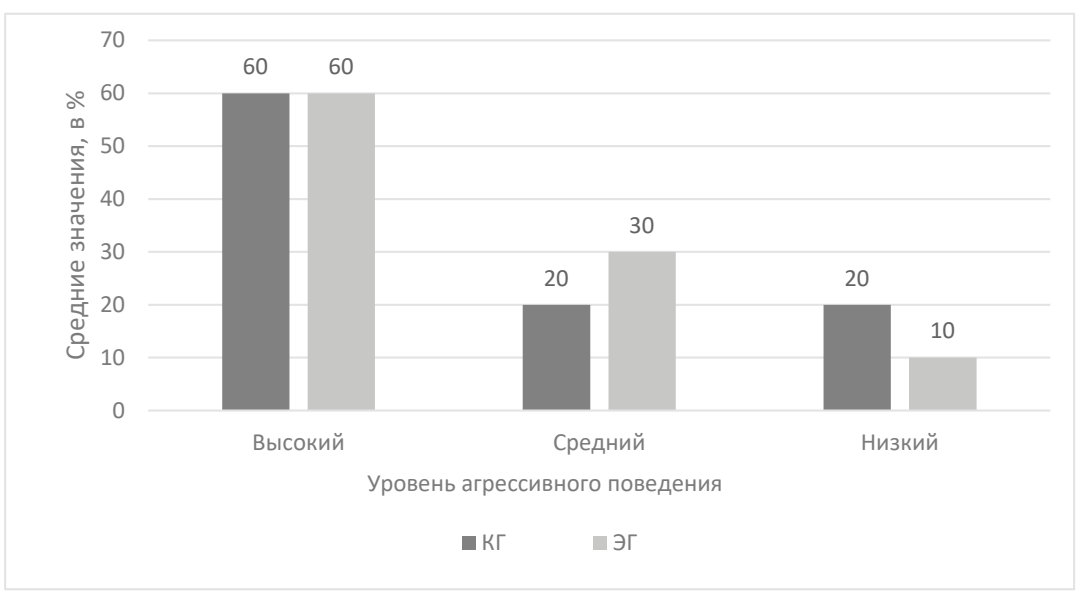

Рuc. 4. Распределение испытуемых КГ и ЭГ по уровню агрессивного поведения на констатирующем этапе эксперимента

психолого-педагогической коррекции является снижение агрессивности подростков посредством сброса эмоциональной напряженности, исключения патологических стереотипов реагирования, повышения самооценки, а также принятия себя и окружающих.

Основные задачи программы психолого-педагогической коррекции агрессивного поведения подростков из проблемных семей:

1. Устранение неконтролируемых чувств (гнева, злости) у подростков.

2. Освоение навыков самоконтроля своего поведения и развитие умений выражать собственное недовольство в приемлемой форме.

3. Повышение самооценки у подростков.

4. Нормализация эмоционального состояния и развитие чувства эмпатии у подростков.

5. Закрепление положительной коммуникативной модели поведения у подростков.

Индивидуальные консультации были проведены до начала группового тренинга с каждым подростком. В процессе разговора психолог выяснял, почему в повседневной жизни у подростка возникают конфликты с окружающими. В первые минуты подростки демонстрировали безразличное отношение к консультанту, испытывали неудобство и сопротивление. Каждый раз, начиная разговор с подростком, имеющим признаки агрессивного поведения, мы решали задачу «запуска» беседы, то есть организации доверительного и эмоционально-открытого разговора с ним. Нами использовались такие методические приемы, как «Давай думать вместе!» и «Психологический контакт». Подростки рассказывали о своем настроении, поведении, о друзьях и родителях. Они приходили к выводу, что складывающиеся взаимоотношения с окружающими во многом зависят от их поведения.

В групповые тренинговые занятия были включены специально подобранные коррекционные упражнения и игры, релаксационные упражнения, направленные на снижение агрессивного поведения у подростков, а также овладение допустимыми способами выражения гнева, развитие навыков эффективного межличностного взаимодействия, обучение навыкам конструктивного взаимодействия в конфликтной ситуации, формирование эмпатии, а также развитие самоконтроля. 
Применяя на занятиях специальные коррекционные упражнения, мы снимали психоэмоциональное напряжение у подростков, способствовали высвобождению отрицательных эмоций и чувств, развивали эмпатические тенденции, отрабатывали навыки группового взаимодействия и навыки самоконтроля. Например, в упражнении «Довольный или сердитый?» подросткам предлагалось понять и почувствовать, что они осознают, когда они очень рассержены или, наоборот, довольны. Здесь важным является четкое осознание подростками своего внутреннего состояния. Данное упражнение предоставляет им возможность выбора того или иного поведения в зависимости от собственного настроения. Подростки с агрессивным поведением, благодаря этому упражнению, отчетливо осознают, что могут управлять не только своими эмоциями и контролировать их, но и поведением в целом. После подобных игр и упражнений в конце тренингового занятия подросткам необходимо было обсудить, какие возникли у них ощущения и эмоции.

Таким образом, в процессе участия в тренинговых занятиях и индивидуальных беседах у детей подросткового возраста происходило формирование положительных установок в общении с окружающими благодаря развитию эмпатии, а также переоценка негативных эмоций по отношению к другим людям. Для того чтобы убедиться в том, что применение индивидуальных (консультация/беседа) и групповых (тренинг) психологических средств коррекции агрессивного поведения у подростков из проблемных семей было эффективным, нам необходимо провести контрольный этап эксперимента.

На рис. 5 представлены результаты диагностики по методике «Опросник агрессивности А. Басса и А. Дарки» у испытуемых контрольной и экспериментальной групп на контрольном этапе эксперимента.

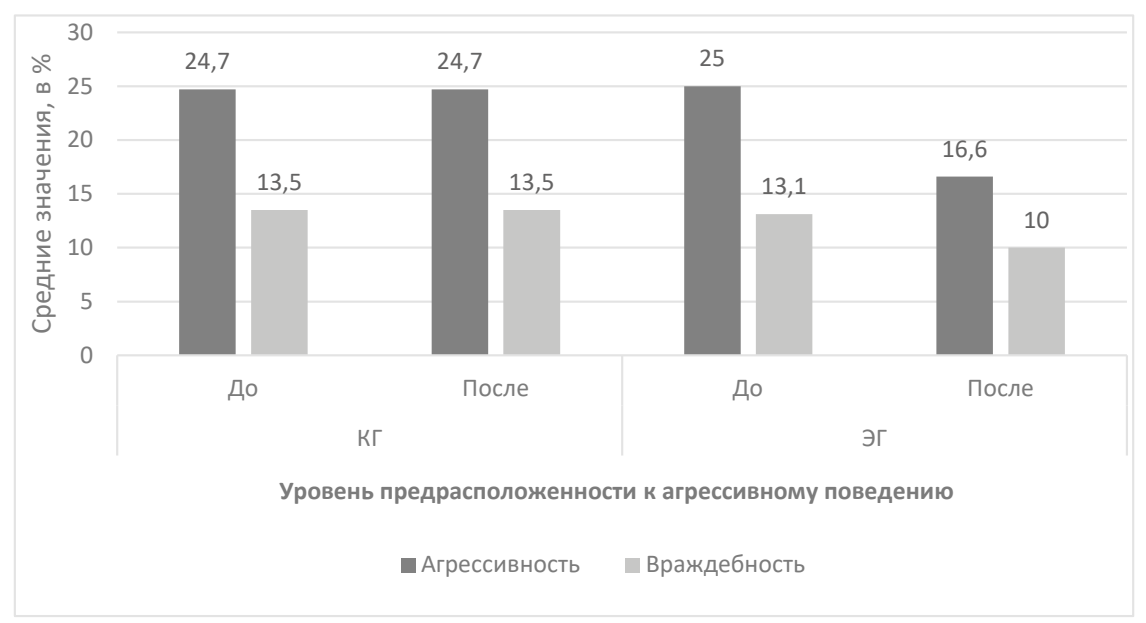

Рuc. 5. Сравнение уровня предрасположенности к агрессивному поведению у испытуемых контрольной и экспериментальной групп («Опросник агрессивности А. Басса и А. Дарки») до и после формирующего этапа эксперимента

Как мы видим из гистограммы, уровень предрасположенности к агрессивному поведению у испытуемых контрольной группы не изменился. В экспериментальной группе произошло снижение уровня предрасположенности к агрессивному поведению. После формирующего этапа эксперимента наблюдается положительная динамика у участников 
экспериментальной группы. Ребята стали более спокойными и уравновешенными в своем поведении, понимают и осознают чувство собственного гнева.

Анализ результатов по методике «Агрессивное поведение» (Е. П. Ильин и П. А. Ковалев), полученных у испытуемых контрольной группы на констатирующем и контрольном этапах, показал, что изменений у них не произошло (рис. 6). В экспериментальной группе произошло снижение показателей по уровню агрессивного поведения. Необходимо отметить, что на констатирующем этапе эксперимента с высоким уровнем агрессивности было 6 подростков (60\%), со средним - 3 (30\%) и низким - 1 (10\%). На контрольном этапе подростков с высоким уровнем агрессивности не обнаружено. Средний уровень был выявлен у 7 ребят (70\%), а низкий - у 3 (30\%). Результаты свидетельствуют о том, что если на констатирующем этапе преобладало много детей с высоким уровнем агрессивности, для которых характерны оскорбления, использование ненормативной лексики, выражение отрицательных эмоций, то на контрольном - преобладание у подростков среднего уровня, с характерными эпизодическими агрессивными действиями, проявляющимися, например, в толкании сверстника, в употреблении обидных слов. С низким уровнем агрессивных тенденций в данной группе испытуемых не выявлено.

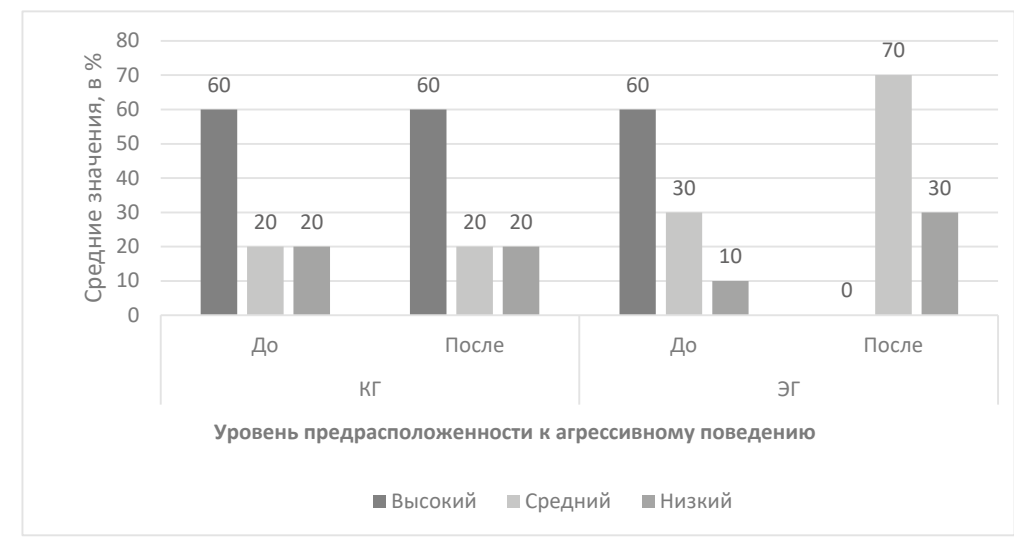

Рuc. 6. Сравнение уровня предрасположенности к агрессивному поведению у испытуемых контрольной и экспериментальной групп («Агрессивное поведение»

Е. П. Ильина и П. А. Ковалева) до и после формирующего этапа эксперимента

Результаты применения методики «Диагностика враждебности (по шкале Кука Медлей)» представлены на рис. 7.

Сравнение полученных результатов на констатирующем этапе показало, что у большинства испытуемых в контрольной и экспериментальной группах был высокий и средний уровни агрессивности. На контрольном этапе в контрольной группе изменений не произошло. В экспериментальной группе показатели по данным шкалам снизились. Можно констатировать, что в экспериментальной группе у 1 испытуемого (10\%) - высокий показатель по данным шкалам. У 6 испытуемых (60\%) - средний уровень враждебного поведения, их агрессивность, враждебность и цинизм выражены умеренно и не превышают норму. Низкий уровень был выявлен у 3 подростков (30\%) , поведение которых в большинстве случаев носит нормальный характер, они неагрессивны. 


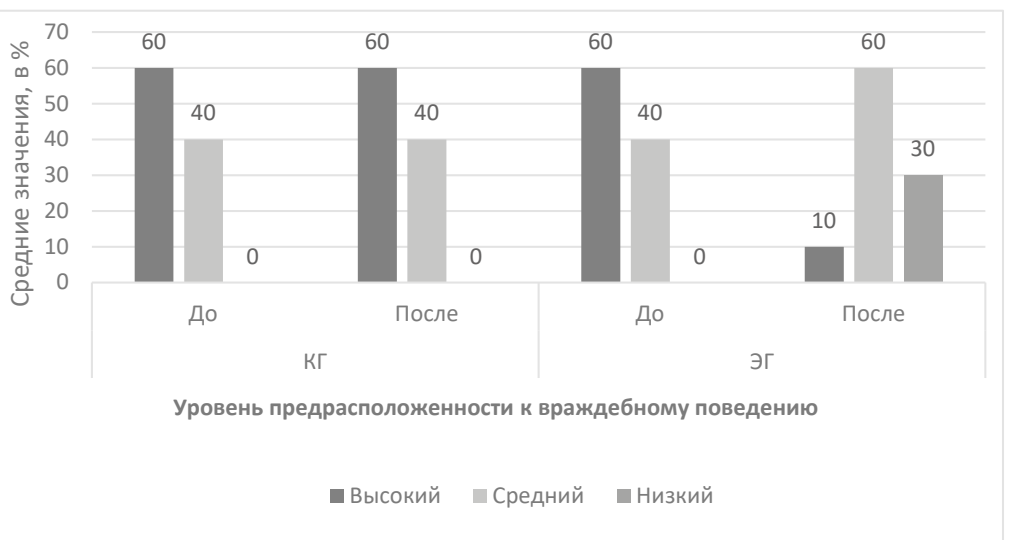

Рuс. 7. Сравнение уровня предрасположенности к враждебному поведению

у испытуемых контрольной и экспериментальной групп («Диагностика враждебности (по шкале Кука - Медлей)») до и после формирующего этапа эксперимента

Для проверки достоверности полученных результатов исследования необходимо применить методы математико-статистической обработки данных. Статистические методы представляют собой базовый инструментарий обработки данных измерений в научном исследовании. Для установления направления сдвига исследуемого признака в двух выборках, то есть показателей агрессивного поведения в экспериментальной и контрольной группах, нами был использован критерий G (критерий знаков). Данный критерий направлен на определение того, изменяются ли значения от одного измерения к другому, то есть происходит ли снижение или повышение переменной.

Данные, полученные у испытуемых экспериментальной группы на констатирующем и контрольном этапах, мы проверили при помощи данного критерия.

Были сформулированы следующие статистические гипотезы:

- Гипотеза Н - преобладание типичного (отрицательного) сдвига в показателях агрессивного поведения у испытуемых является случайным.

- Гипотеза $\mathrm{H}_{1}$ - преобладание типичного (отрицательного) сдвига в показателях агрессивного поведения у испытуемых не является случайным.

Проверим данные гипотезы, определив критические значения G-критерия по та-

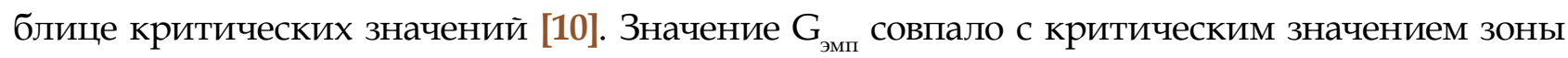
значимости $\mathrm{G}_{\text {кр }}$ для $\mathrm{p}<0,01$. Следовательно, можно утверждать, что полученный в результате экспериментального исследования сдвиг в показателях уровней агрессивного поведения у подростков из проблемных семей статистически значим на 1-процентном уровне. Таким образом, в результате применения индивидуальных (консультация/беседа) и групповых (тренинг) психологических средств показатели агрессивного поведения у испытуемых значительно снизились. Данные сдвиги статистически достоверны. Переформулируем полученный результат в терминах статистических гипотез: поскольку преобладание типичного отрицательного направления сдвига в данном случае не случайно, то, следовательно, на 1-процентном уровне может быть принята гипотеза $\mathrm{H}_{1}$ о наличии различий.

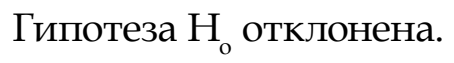


Иначе говоря, применение индивидуальных (консультация/беседа) и групповых (тренинг) психологических средств коррекции агрессивного поведения у подростков из проблемных семей было эффективным. Данные психологические средства воздействия привели к существенным изменениям в снижении уровней агрессивного поведения подростков из проблемных семей.

Подводя итоги проведенной работы по выявлению эффективности индивидуальных (консультация/беседа) и групповых (тренинг) психологических средств коррекции агрессивного поведения подростков, воспитывающихся в проблемных семьях, можем утверждать, что результаты, полученные после формирующего этапа эксперимента, убедительно показывают положительные изменения.

\section{Список литературы}

1. Городилова М. А., Бочанщева Л. И. Особенности проявления агрессивности у подростков из семей с алкогольной зависимостью // Международный студенческий научный вестник. 2018. № 5. URL: http://www.eduherald.ru/ru/article/ view?id=18659 (дата обращения: 12.09.2019).

2. Большой психологический словарь / Б. Г. Мещеряков; под ред. Б. Г. Мещерякова, В. П. Зинченко. М.: Прайм-Еврознак, 2013. 672 с.

3. Можгинский Ю. Б. Агрессивность детей и подростков: распознавание, лечение, профилактика. Изд. 2-е, стер. М.: Когито-Центр, 2008. 181 с.

4. Реан А. Психология детства. СПб.: Прайм-Еврознак, 2003. 368 с.

5. Посысоељ Н. Н. Основы психологии семьи и семейного консультирования: учеб. пособие для студ. высш. учеб. заведений / под общ. ред. Н. Н. Посысоева. М.: Владос-Пресс, 2004. 328 с.

6. Бубнова Л. И. Социализация как фактор становления личности и девиации ее поведения // Философия образования. Новосибирск, 2006. С. 178-182.

7. Кипрюшина А. А., Бобкова М. Г. Особенности детско-родительских отношений в дисфункциональных семьях и их влияние на формирование эмоционального состояния личности подростка (на примере девиантных подростков) // Материалы VII Междунар. студенческой науч. конф. «Студенческий научный форум». Тобольск: Филиал ТГУ, 2014. URL: https://scienceforum.ru/2015/article/2015017719 (дата обращения: 05.10.2018).

8. Бочанцеља Л. И. Психологические средства нормализации затрудненного общения антисоциальной личности (на примере лиц юношеского возраста): дис. ... канд. псих. наук: 19.00.01. Новосибирск, 2007. 256 с.

9. Бочанцеља Л. И. Влияние социально-психологического тренинга на развитие коммуникативных способностей старшеклассников с агрессивным поведением // Проблемы современного образования. 2018. № 3. C. 68-79. URL: http://pmedu. ru/images/2018-3/08.pdf (дата обращения: 05.10.2018).

10. Ермолаев О. Ю. Математическая статистика для психологов: учебник. М.: Московский психолого-социальный ин-т: Флинта, 2003. 336 с. 


\section{References}

1. Gorodilova M. A., Bochantseva L. I. Osobennosti proyavleniya agressivnosti u podrostkov iz semey s alkogolnoy zavisimostyu. Mezhdunarodnyy studencheskiy nauchnyy vestnik. 2018, No. 5. Available at: http://www.eduherald.ru/ru/article/view?id=18659 (accessed: 12.09.2019).

2. Meshcheryakov B. G. Bolshoy psikhologicheskiy slovar. Moscow: Praym-Evroznak, 2013. $672 \mathrm{p}$.

3. Mozhginskiy Yu. B. Agressivnost detey i podrostkov: raspoznavanie, lechenie, profilaktika. Moscow: Kogito-Tsentr, 2008. 181 p.

4. Rean A. Psikhologiya detstva. St. Petersburg: Praym-Evroznak, 2003. 368 p.

5. Posysoev N. N. Osnovy psikhologii semнi i semeynogo konsultirovaniya: ucheb. posobie dlya stud. vyssh. ucheb. zavedeniy. Moscow: Vlados-Press, 2004. 328 p.

6. Bubnova L. I. Sotsializatsiya kak faktor stanovleniya lichnosti i deviatsii ee povedeniya. In: Filosofiya obrazovaniya. Novosibirsk, 2006. S. 178-182.

7. Kipryushina A. A., Bobkova M. G. Osobennosti detsko-roditelskikh otnosheniy v disfunktsionalnykh semyakh i ikh vliyanie na formirovanie emotsionalnogo sostoyaniya lichnosti podrostka (na primere deviantnykh podrostkov). In: Proceedings of the VII International student scientific conference "Studencheskiy nauchnyy forum". Tobolsk: Filial TGU, 2014. Available at: https://scienceforum.ru/2015/article/2015017719 (accessed: 05.10.2018).

8. Bochantseva L. I. Psikhologicheskie sredstva normalizatsii zatrudnennogo obshcheniya antisotsialnoy lichnosti (na primere lits yunosheskogo vozrasta). PhD dissertation (Psychology). Novosibirsk, 2007. 256 p.

9. Bochantseva L. I. Vliyanie sotsialno-psikhologicheskogo treninga na razvitie kommunikativnykh sposobnostey starsheklassnikov s agressivnym povedeniem. Problemy sovremennogo obrazovaniya. 2018, No. 3, pp. 68-79. Available at: http://pmedu.ru/images/ 2018-3/08.pdf (accessed: 05.10.2018).

10. Ermolaev O. Yu. Matematicheskaya statistika dlya psikhologov: uchebnik. Moscow: Moskovskiy psikhologo-sotsialnyy in-t: Flinta, 2003. 336 p.

Интернет-журнал

«Проблемы современного образования"

2019, № 5

Статья поступила в редакцию 08.04.2019

The article was received on 08.04.2019 